\title{
Europa, het bindweefsel van mijn hart
}

Citation for published version (APA):

Heymans, S. R. B. (2012). Europa, het bindweefsel van mijn hart. Maastricht University. https://doi.org/10.26481/spe.20120525sh

Document status and date:

Published: 25/05/2012

DOI:

10.26481/spe.20120525sh

Document Version:

Publisher's PDF, also known as Version of record

\section{Please check the document version of this publication:}

- A submitted manuscript is the version of the article upon submission and before peer-review. There can be important differences between the submitted version and the official published version of record.

People interested in the research are advised to contact the author for the final version of the publication, or visit the DOI to the publisher's website.

- The final author version and the galley proof are versions of the publication after peer review.

- The final published version features the final layout of the paper including the volume, issue and page numbers.

Link to publication

\footnotetext{
General rights rights.

- You may freely distribute the URL identifying the publication in the public portal. please follow below link for the End User Agreement:

www.umlib.nl/taverne-license

Take down policy

If you believe that this document breaches copyright please contact us at:

repository@maastrichtuniversity.nl

providing details and we will investigate your claim.
}

Copyright and moral rights for the publications made accessible in the public portal are retained by the authors and/or other copyright owners and it is a condition of accessing publications that users recognise and abide by the legal requirements associated with these

- Users may download and print one copy of any publication from the public portal for the purpose of private study or research.

- You may not further distribute the material or use it for any profit-making activity or commercial gain

If the publication is distributed under the terms of Article $25 \mathrm{fa}$ of the Dutch Copyright Act, indicated by the "Taverne" license above, 
Dr. S.R.B. Heymans

Faculty of Health, Medicine and Life Sciences

\section{Europa, het bindweefisel van mijn hart}




\section{Europa, het bindweefsel van mijn hart.}

Prof.dr. Stephane Heymans, Hoogleraar Idiopathische Cardiomyopathieën

FHML, Afdeling Cardiologie,

Cardiovascular Research School Maastricht (CARIM), UM

Vrijdag 25 mei 2012.

Mijnheer de Pro-Rector en Decaan,

Lieve schat, kinderen, familie en vrienden,

Beste collega's en bekenden,

Geachte overige aanwezigen,

Op het eerste gezicht heeft Europa niets te maken met het hart. Sterker nog, de Europese Unie en het hart zijn als vuur en water, politiek en wetenschap, niet echt met elkaar te verzoenen. Hoe kom ik dan tot die stelling "Europa, het bindweefsel van mijn hart"?

Europa, het bindweefsel van mijn hart

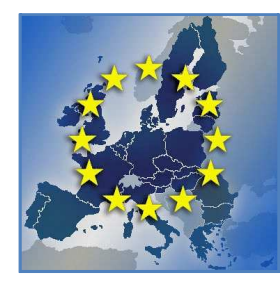

C Netherlands $1972 \cdot$ forty years $\bullet 2012$

$$
0^{\circ}=
$$

Maastricht UMC
Het feit dat ik, Belg zijnde, mijn oratie voordraag als hoogleraar aan de Universiteit Maastricht en het Nederlands Hart Instituut ICIN, dank ik grotendeels aan dit bindweefsel, het hart en het Europees eenmakingproces. De Universiteit Maastricht, de onderzoeksscholen zoals CARIM, en het Nederlands Hart Instituut ICIN zijn immers kinderen, broertjes, van deze Europese eenwording. Ze zijn experimentele speeltuinen voor Europa. Zoals ik graag meer samenwerking zou willen zien binnen en tussen deze onderzoeksscholen, zo ook is meer Europa nodig om te komen tot welvaart en stabiliteit.

Ik vind dat meer eenheid van ziekenzorg, werk, sociale wetgeving, wetenschap, en hieraan gerelateerde geldstromen binnen de Europese Unie noodzakelijk zijn voor economische groei, vrede en welvaart binnen Europa.

Mijn visie is dan ook dat instrumenten zoals de onderzoeksscholen in Maastricht, het Nederlands Hartinstituut ICIN die de 8 cardiologische Universitaire centra met elkaar verbindt, het Cardiovasculair Onderzoek Nederland, en de consortia in Europa, allen bindweefsel zijn voor samenwerking binnen het cardiovasculair wetenschappelijk onderzoek. Zij bundelen de wetenschappelijke krachten, en zijn verweven met de Europese gedachte dat eendracht en samenwerking krachtiger maakt. Ze bieden een ruimte van vrijheid en veiligheid voor dit wetenschappelijk onderzoek.

Wat hebben deze Euroregionale en Europese samenwerkingen te maken met het bindweefsel van het hart en haar functie? Zoals de Europese Unie het bindweefsel is voor economische, politieke en wetenschappelijke eenheid binnen Europa, en het ICIN, CVON en de onderzoeksscholen dit doen in Nederland; zo ook is het bindweefsel uiterst belangrijk voor de integriteit en functie van het hart. Zo eenvoudig. Het bindweefsel collageen, het staal van het hart, voorkomt dat het hart gaat falen of breken, met plotse dood tot gevolg. Het collageen, het bindweefsel in het hart, heeft een structuur die sterk gelijkt op deze van staal. Ze zijn praktisch niet van elkaar te onderscheiden. 


\section{Staal verenigt Europa.}

Collageen, het staal van het hart, zorgt dus voor een goede functie en samenhang van het hart. Het collageen is aanwezig tussen de verschillende hartspiercellen, en bindt deze aan elkaar. Dus, zonder dit staal, het collageen, geen hart. Ook Europa was niet ontstaan zonder staal. Nog een

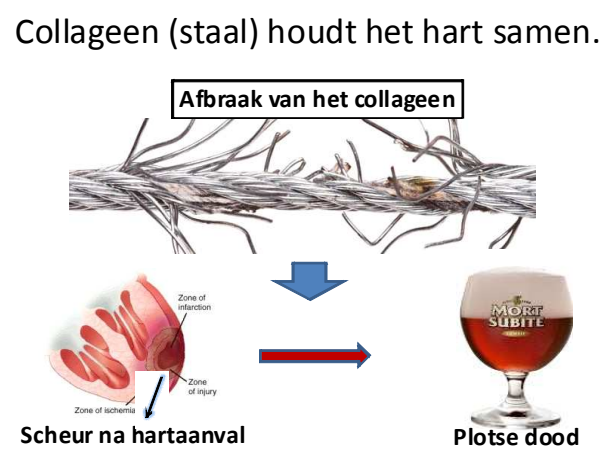
parallel tussen Europa en het hart. Immers, Wereldoorlog II werd vooral mogelijk gemaakt en actief gesteund door de sterke staal- en koolindustrie. $\mathrm{Na}$ Wereldoorlog II verenigden zes Europese landen waaronder België, Nederland en Luxemburg, gevolgd door Duitsland, Frankrijk en Italië, zich economisch in de Europese Gemeenschap voor Kolen en Staal, dit om te zorgen voor een blijvende vrede na de gruwelijke wereldoorlogen. Dit Verdrag voor Kolen en Staal werd getekend in 1952. Staal was dus het eerste bindweefsel voor het hart van Europa.

Door de Europese landen van elkaar afhankelijk te maken voor steenkool en staal, zou een Europees land zich niet langer zonder medeweten van de rest kunnen bewapenen. Dit verminderde na Wereldoorlog II dan ook het wantrouwen en de spanning. Voortbouwend op dit succes van het Verdrag voor Kolen en Staal, breidden de zes landen hun samenwerking uit tot andere economische sectoren. Zij richten een gemeenschappelijke markt op binnen het Verdrag van Rome, met de geboorte van Europese Economische Gemeenschap (EEG), of "gemeenschappelijke markt". Vrij verkeer van personen, goederen, diensten over de grenzen was het achterliggende idee. Zonder staal zou Europa dus nooit met elkaar gebonden zijn geweest.

\section{Staal houdt het hart bij elkaar}

Ook het hart zou zonder staal uit elkaar vallen. Het breken van het collageen, het bindweefsel dat de hartspiercellen aan elkaar bindt, doet het hart scheuren, dit bijvoorbeeld na een hartinfarct, met

Staal brengt Europa bij elkaar.

Het Verdrag van Kolen en Staal, 1952

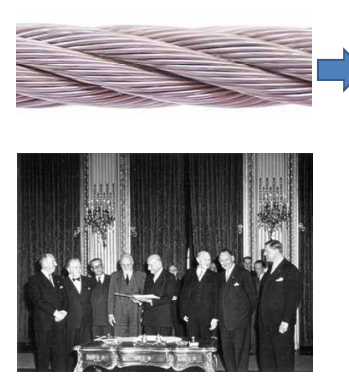

plotse dood tot gevolg. Plotse dood, in het Latijn ook wel "Mors Subita" of Mort Subite in het Frans. Dit laat me toe terug te keren naar mijn jeugd. Mort Subite is immers een heerlijke geuze gebrouwen in mijn geboortedorp Asse en Kobbegem. Deze geuze heeft een zoetzure smaak, en is heerlijk bij wild of verfrissend als aperitief.

Toen ik besloot in 1988 om arts, Cardioloog en onderzoeker te worden, verliet ik dit heerlijk bierbrouwende Pajottenland, en ruilde het in voor de iets wat serieuzere professoren stad

Leuven. Daar wilde ik immers onderzoeken hoe deze geuze, de Morse Subite, in verband stond met hart. Hoe ontstaat plotse dood na een hartinfarct? Onder de deskundige begeleiding van Professor dr. Peter Carmeliet en Professor dr. Désiré Collen besloot ik dit vraagstuk binnen een doctoraat van vier jaar op te lossen. Ik toonde aan dat het eigen hart niet kan zonder dit bindweefsel, zonder collageen, het staal in het hart. Afbraak ervan na een hartinfarct door staal afbrekende eiwitten bleek de reden te zijn voor het uitzetten en falen, alsook voor het breken van het hart na een hartaaval, "slagaderbreuk" in de volksmond. Dus: zoals de Europese landen niet met elkaar zouden verbonden zijn zonder staal, zo ook breekt het hart zonder dit staal, het collageen.

Collageen, het staal van het hart, voorkomt plotse dood. 
Wat is dit collageen? Het is het bindweefsel dat de verschillende hartspiercellen met elkaar verbindt. Collageen is zelf sterker dan staal: de trekvastheid is groter dan dat van staal. Onder de microscoop zie je dus letterlijk staaldraden die met elkaar verweven zijn, en staalkabels vormen. Ze zijn het skelet van het hart, waartussen de hartspiercellen samentrekken. Mijn wetenschappelijk werk toonde

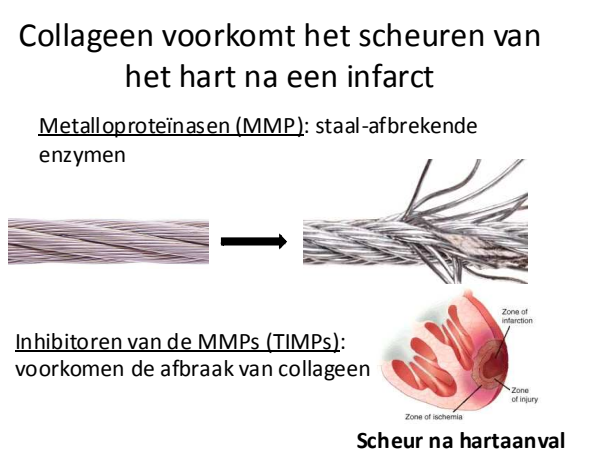
aan dat een verhoogde afbraak van dit collageen door metalloproteïnasen, letterlijk de metaal- of staalafbrekende enzymen, na een hartaanval, leidde tot het scheuren of "ruptuur" van het hart, met plotse dood, Mors Subita, tot gevolg. Deze staal-afbrekende enzymes, de metalloproteinasen zijn dus de "bad guys", die gelukkig worden tegengewerkt door de "good guys", de inhibitoren van deze eiwitten, de TIMPs (of tissue inhibitors of MMPs). Deze TIMPs zorgen ervoor dat het nieuw aangemaakte collageen niet opnieuw wordt afgebroken, en stabiliseren aldus het staal in het hart.

\section{Matricellulaire eiwitten: de politieke en monetaire macht in Europa.}

Staal is dus het bindweefsel van het hart, en staal was ook het bindweefsel voor Europa om samen te werken op economisch vlak, hand in hand met welvaart en vrede. Het inzicht kwam echter snel dat economische samenwerking niet voldoende was. Europa had nood aan nieuwe dimensies naast het economische, namelijk het monetaire en politieke. Zo ook, zocht ik naar een nieuwe dimensie in het bindweefsel van het hart. Aldus toonde mijn onderzoek aan dat niet alleen het collageen, de staaldraden afdoende zijn om het hart bij elkaar te houden, doch dat er een bijkomend bindweefsel dimensie nodig is om het hart te beschermen tegen uitzetten, falen en hartbreuk.

De niet-structurele matri-cellulaire eiwitten bleken deze bijkomende dimensie in het hart zijn. Dit zijn stofjes die niet onmiddellijk het hart met staal bij elkaar houdt, zoals het collageen. Het zijn stofjes die de functie van de verschillende harspiercellen coördineren. Ze zorgen voor sterker collageen, doen de hartspiercellen langer leven, en voorkomen ontsteking in het hart.

\section{Collageen en matricellulaire eiwitten}

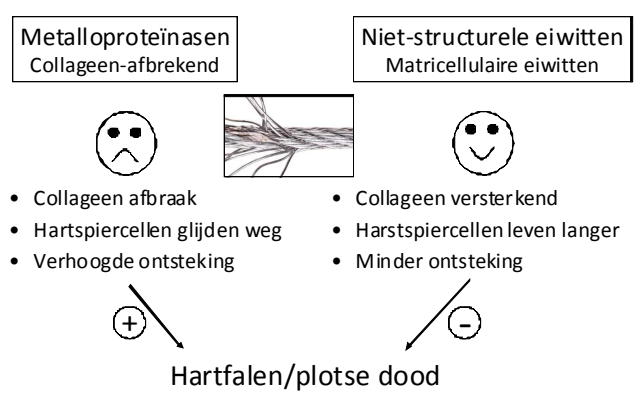

Hierbij denk ik aan thrombospondin en osteonectin, de monetaire en politieke macht in het hart. Ten eerste binden ze het collageen: ze maken het collageen sterker doordat ze de vorming van staalkabels bevorderen. Een toename van deze eiwitten bij ziekte behoedt het hart tegen een slechte functie en overlijden van de hartspiercellen, en beletten onaangepaste ontsteking in het hart. Zoals het hart thrombospondin en osteonectin nodig heeft om te overleven, zo ook heeft Europa een goede monetaire

en politieke aansturing nodig om zich te handhaven. Dit is een vereiste om uitschuivers zoals Griekenland te voorkomen, om het ziek worden van het Europese hart tegen te gaan. Ik zie de Europese politici als de systeembiologen die met de input van de technocraten, de basale onderzoekers, het werkingsproces van Europa verduidelijken en de juiste beslissingen nemen die het individuele belang van elk Europees land zal overstijgen.

Technocraten dienen samen te werken met de politici. Zo ook zal een partnership tussen wetenschappers en de systeembiologen de kennis van de wetenschap verenigen tot een vierde dimensie. De gezamenlijke inzet van de technocraten en de politici -de systeembiologen- is noodzakelijk om het Europese procesvorming voor economisch integratie inzichtelijker te maken en een goed beleid toe te laten. Ik vind dat de mobiliteit tussen de verschillende landen dient vergroot te 
worden, en dat de kunstmatige grenzen voor sociaal, fiscaal en financieel beleid dienen afgebroken te worden. Dit zal helpen deze integratie verder te versterken.

Ook binnen de wetenschap in Nederland, de Benelux en Europa is het nodig de krachten te bundelen en grenzen op te heffen: dit versnelt het onderzoek, en voorkomt dubbel werk. Hiervoor heb je mensen met visie nodig die dit proces aansturen en de funding mechanismen hierop africhten.

Hoe heb ik aangetoond dat deze twee politieke leiders in het hart beschermend zijn tegen een hartcrisis? Hiervoor gebruikte ik muisjes waarbij het gen voor deze eiwitten is uitgeschakeld, de "gen knockout" muisjes. Deze en hun normale tegenhangers, die wel nog het gen voor thrombospondin of osteonectin hebben, ondergaan vervolgens een hartinfarct, een te hoge bloeddruk of een virale infectie in het hart. Het ontbreken van één van deze eiwitten in de muisjes had dramatische gevolgen. Het leidde tot een forse uitzetting, functie verlies en zelf scheuren van het hart. Hartspiercellen gaan sneller dood, het collageen verzwakt, en ontsteking neemt toe. Deze eiwitten zijn dus nodig om het hart te beschermen tegen hartfalen en plotse dood. Het zijn dus de noodzakelijk leiders in het hart van Europa, en zonder hun controle over de vorming van het bindweefsel, zou het hart, ons Europa, niet overleven en uit elkaar vallen.

\section{De Universiteit Maastricht en ICIN: "the Sixty Folies" in Europa.}

Hoe staan het Nederlands Hartinstituut en het de Universiteit Maastricht in verband met Europa?

Niet alleen Europa, ook het Medisch Universitair Centrum, en het Nederlands Hartinstituut ICIN vormen het bindweefsel van mijn wetenschappelijk

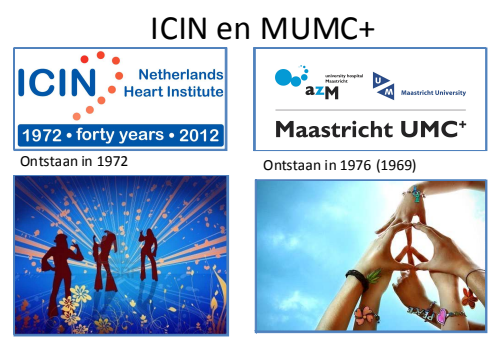
onderzoek. Ze liggen me nauw aan het hart. Ze zijn dan ook mijn twee voornaamste gastheren hier in Nederland. Beiden ondersteunen ze de Europese gedachte dat het bundelen van de krachten binnen het onderzoek leidt tot een grotere wetenschappelijke welvaart en betere resultaten. Ook hun beider ontstaan loopt parallel met deze van de Europese Unie, alsook met de bewogen jaren ' 68 . Ze zagen het daglicht in de periode van de dansende hippies, de "Swinging Sixties ". Gedurende deze culturele revolutie ontstond een nieuwe generatie leiders en onderzoekers die wilden breken met oude gewoontes. Deze generatie van mei '68 was expansief en vernieuwend, en geloofde heel sterk in samenwerking "peace and love" als basis voor de nieuwe maatschappij. Het Europese eenwordingsproces was de bakermat voor vele samenwerkingsverbanden, zoals ook het Nederlandse Hartinstituut ICIN, en de Maastrichtse onderzoeksscholen, waaronder het cardiovasculaire CARIM.

Ik ervaar dagelijks dat vernieuwing, expansie en samenwerking nog steeds de voornaamste drijfveren zijn binnen de Universiteit Maastricht: "leading in learning". Onze universiteit ontstond na de rellen van mei 1968, met bovendien als eerste de faculteit Geneeskunde. Immers, een tekort aan opleidingsmogelijkheden tot arts eind jaren zestig resulteerde in de behoefte aan een achtste medische faculteit in Nederland. Mede door de mijnsluitingen in Limburg, en gestuurd door deze krachtig dynamiek van de ' 68 generatie, besloot de Nederlandse regering in 1969 tot het oprichten van een Limburgse Euregionale universiteit: de Rijksuniversiteit Limburg, die in 1976 haar deuren opende. Deze nieuwe Maastrichtse Universiteit wilde zich echter niet beperken tot het creëren van nieuwe opleidingsplaatsen voor artsen, doch koos ook heel snel voor grensverleggende vernieuwing zowel binnen het onderwijs als het wetenschappelijk onderzoek. Maastricht koos voor een nieuw onderwijssysteem, het Probleemgestuurd Onderwijs, en werd wereldwijd beroemd als Europese grondlegger van dit onderwijsmodel. Dit kennisproduct wordt tot de dag van vandaag geëxporteerd 
naar andere Europese Universiteiten zoals Gent, Turijn en vele anderen; vandaar ook het motto van de Universiteit "Leading in Learning".

De universiteit groeide bijzonder snel. Eerst door politieke steun, later door de keuze om bewust nieuwe wegen in te slaan, vaak ingaand tegen de gangbare universitaire Nederlandse groeimodellen. Maastricht koos bewust voor meer Europees gerichte opleidingen zoals Internationale Bedrijfskunde, European Law School, European Studies en European Public Health. Inmiddels komt 43\% van de Maastrichtse studenten uit het buitenland. Daarmee is de Universiteit

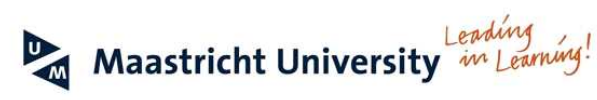

- 1965: sluiting van limburgse mijnen

- 1969: besluit tot op richting limburgse universiteit

- 1976: opening van de Rijksuniversiteit Limburg

- Onderzoeksscholen

- Probleemgestuurd onderwijs

- Internationaal

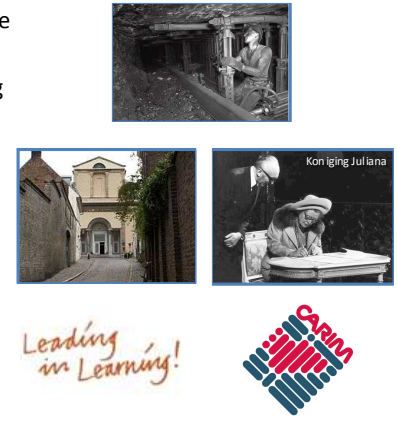

Maastricht één van de meest internationale universiteiten in Europa.

Ook het onderzoek werd georganiseerd naar het Europese model. De individuele vakgroepen binnen de Medische Wetenschappen zoals Fysiologie, Farmacologie, Pathologie, Interne Geneeskunde en Cardiologie, werken nu samen binnen onderzoeksscholen, zoals CARIM, NUTRIM, CAPHRI en GROWTH. Individuele vakgroepen worden gebundeld zowel in ruimte, structuur alsook financieel. Dit helpt om de individuele belangen te overstijgen in een groter gemeenschappelijk geheel.

Hoe verder met deze onderzoeksscholen? Zijn de huidige modellen aan vernieuwing toe? Zoals de Europese Unie momenteel groeit en verandert van crisis tot crisis, zo ook zal CARIM krachtiger worden door verandering. Meer coherentie en gezamenlijke beslissingskracht, en het verleggen van de grenzen naar andere onderzoeksscholen, universiteiten en Europese partners, zal de daadkracht, en de politieke en monetaire waarde van CARIM vergroten. Goede regels, en de mogelijkheid tot controle en centrale aansturing maken het mogelijk om minder goed functionerende elementen, zoals bv Griekenland binnen Europa, op tijd te corrigeren.

De huidige financiële en politieke crisis binnen Europa ontstond door een financieel wanbeheer in de zwakkere Zuiderse landen, die onvoldoende werden verantwoordelijk gesteld. Ook binnen het onderzoek speelt deze crisis. Oplossing hierbij is niet de sterkere spelers meer te gaan belasten: zij ondersteunen immers de economie en de wetenschap. Landen en partners die het minder goed doen, dienen -in mijn optiek- duidelijkere richtlijnen te krijgen voor hun beleid en resultaten, en de sterkeren kunnen dit proces van nabij mee aansturen. Binnen CARIM en de universiteit is het nodig om de dynamische mensen actief te betrekken bij het beleid: zij zijn immers de economische en politieke motor. Hun extra belasten om de zwakkere mensen te doen overleven is contra-productief. Richtlijnen over het wervend vermogen en hun output zijn nodig: de economische balans binnen de wetenschap.

Mijn visie is dat ook meer schooloverstijgende interacties nodig zijn. Meer samenwerking met een gemeenschappelijk gebruik van apparatuur, mensen en ruimtes zal leiden tot betere wetenschap, efficiënter gebruik van middelen en een positiever balans in de output. Voorbeeld hiervan is het bundelen van het metabole en het cardiovasculaire onderzoek.

De paradox dat te weinig eenheid leidt tot een minder goed functioneren van de Europese unie, doet sommige mensen beslissen dat deze Europese Unie moet afgeschaft worden of afgebouwd. Het kind met het badwater weggooien. De verkeerde maatregel omwille van ongewenste effecten. Om Europa, en onderzoeksinstituten als CARIM, ICIN en anderen beter te doen functioneren, dienen we ze niet af te breken, doch juist meer middelen te geven om hun integratie te bevorderen. Ik kijk uit naar een Europese variante van deze onderzoeksscholen, met aansturende leden, vooral actieve clinici en onderzoekers, die projecten, onderwijs, en middelen integreren. ledereen weet dat het 
moeilijk is, tot er iemand komt die dat niet weet. Immers, ook de 'De eurocrisis is een treinramp in slow motion'; als we willen voorkomen dat de Eurozone uit elkaar valt, dienen we extra te investeren in innovatie en excellentie, om ze een nieuwe impuls te geven.

\section{Het Nederlands Hartinstituut ICIN.}

Naast de Universiteit Maastricht, is ook het Nederlandse Hartinstituut ICIN een kind van het Europese eenmakingproces. In de jaren 70 traden andere Europese landen, waaronder ook Denemarken, lerland en het Verenigd Koninkrijk toe tot de Europese Economische Unie. De korte, maar hevige Arabisch-Israëlische oorlog van oktober 1973 leidt tot een energiecrisis en economische problemen in Europa. De laatste rechtse dictaturen in West-Europa komen ten

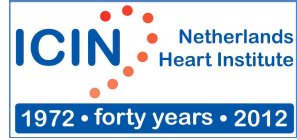
val: het Salazar-regime in Portugal wordt in 1974 omvergeworpen en in Spanje sterft generaal Franco in 1975. In het kader van het Europees regionaal beleid worden grote sommen overgedragen om werkgelegenheid en infrastructuur te creëren in deze armere streken. In deze drukke jaren voor Europa richt Professor dr. Dirk Durrer het ICIN op. Het Nederlands Hartinstituut staat voor een huwelijk

- 1970-1975: Europese uitbreiding

- 1972: Prof.dr. Durrer richt ICIN op

$>$ Samenwerking tussen 8 cardiologische universitaire centra

$>$ Afdelings/onderzoekshoofden + "jonge" hoogleraren tussen de verschillende cardiologische universitaire afdelingen in Nederland. In een tijd dat de meeste academische ziekenhuizen nog niet eens een aparte afdeling Cardiologie kenden, dacht Professor Durrer al aan een bundeling van de academische cardiologische krachten. Hij deelde de Europese visie dat de som groter is dan de afzonderlijke delen.

Vandaag is deze interactie tussen de verschillende academische afdelingen nog steeds het belangrijkste uitgangspunt voor het werk binnen ICIN. De hoofden van cardiologie en de cardiovasculaire onderzoeksscholen, alsook een 8-tal jongere ICIN hoogleraren waaronder ik, komen eenmaal per maand samen in Utrecht om gemeenschappelijke projecten voor klinisch of wetenschappelijk onderzoek te bespreken. Hoe een sterke visie in de jaren 70 , gebonden aan de Europese eenmaking, tot de dag van vandaag een sterk instrument vormt voor inter-universitaire interactie en elkaar versterkende projecten. Een huwelijk dus tussen de verschillende cardiologische afdelingen.

\section{5. "Idiopathische Cardiomyopathieën” : mijn taak binnen het MUMC+ en ICIN.}

Wat is mijn klinische en wetenschappelijk taak binnen het ICIN en de Universiteit Maastricht? Wat betekent mijn huwelijk met het ICIN en het MUMC+. Want een huwelijk, weliswaar met ICIN, betekent dat een man zijn rechten halveren en zijn plichten verdubbelen. Mijn hoogleraar benoeming betreft de "Idiopathische Cardiomyopathieën", letterlijk hartproblemen waarbij de oorzaak niet zo goed gekend is.

Hoe kan je hoogleraar zijn van iets waarvan je de oorzaak niet kent? Of het is zo dat mannen gelukkig zijn, omdat onwetendheid een zegen is? Nee, "idiopathisch" staat hier voor hartaandoeningen in de afwezigheid van een hartinfarct of kleplijden, de voornaamste oorzaken van hartfalen. Een bron van onderzoek en nieuwe kennis. Geen hartinfarct, geen kleplijden; wat is het dan wel? Wie zijn deze patiënten? 
Deze cardiomyopathieën treffen vooral jongere mensen die nog volop beroepsactief zijn, een gezin opbouwen en nog veel toekomstplannen hebben. De gemiddelde leeftijd is 44, en hun hartprobleem komt vaak als een donderslag bij heldere hemel. Gedurende mijn opleiding tot cardioloog maakte ik
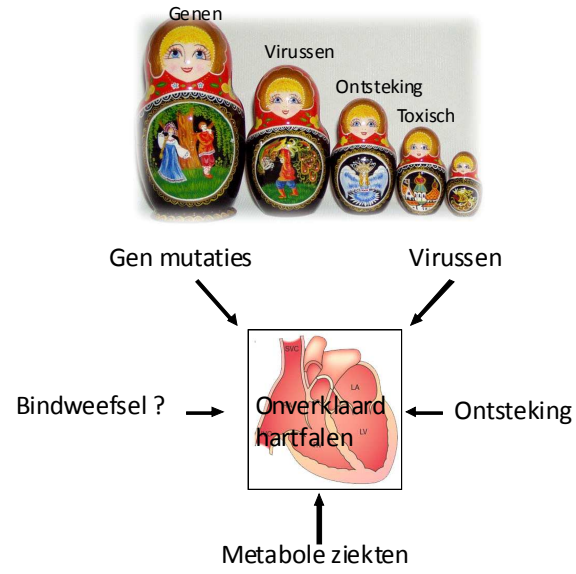
mee dat twee jonge mannen, vaders, plots dood gingen, waarbij achteraf bleek dat een verkoudheidsvirus in het hart veel ontsteking en schade had aangericht. Ik begreep niet waarom een anders zo onschuldig verkoudheidvirus zoveel schade aanrichtte in het hart. Waarom juist die ene man en niet die vele anderen die een verkoudheid hebben? Of hoe kan een kou leiden tot de verbranding van het hart...

De kennis over het ontstaan van hartfalen bij deze jonge mensen is nog steeds beperkt: een geschenk voor elke jonge nieuwsgierige

wetenschapper zoals ik. Mede onder impuls van Professor dr. Yigal Pinto, Professor dr. Harry Crijns en Professor dr. Mat Daemen startte ik een zorgprogramma voor deze jonge hartfalers. Ik aanvaard daarom heel graag de taak om deze verpakking te openen, en te ontdekken welke verrassingen het biedt. Het is immers een geschenk als een Russische popje, een matroesjka. Telkens als ik een popje wegneem en een oorzaak ontdenk, kom ik een ander popje tegen, een nieuwe oorzaak. Foute genen, virussen, ontstekingen, kankerbehandeling of zeldzamere stapelingsziekten: het zijn allemaal oorzaken die met elkaar verweven zijn, en elkaar beïnvloeden. Gesteund door mijn collega's binnen de afdeling Cardiologie, de Nederlandse Hartstichting, en het ICIN, beleef ik dagelijks werkplezier aan dit discipline overstijgend werk.

Dit is multidisciplinair werk, omdat ik steun ik op vele andere mensen: collega's cardiologen voor de patiënten en biopten, medisch microbiologen om de virussen op te sporen, pathologen voor het microscopisch onderzoek, en immunologen voor ontstekingsziekten. Wederom een mooi voorbeeld hoe samenwerking tussen verschillende vakgroepen, leidt tot meerwaarde: een beter inzicht over een bepaalde ziekte. Meer dan 70 percent van deze jonge hartfalers wordt verwezen van buiten ons ziekenhuis: regionale en andere universitaire centra.

\section{Myocarditis: een liefde-haat verhouding tussen een virus en het hart.}

Hoe kan een gewoon verkoudheidvirus het hart schaden. Of hoe een kou het hart kan doen

Hoe kan een virus $\rightarrow$ schade aan het hart?

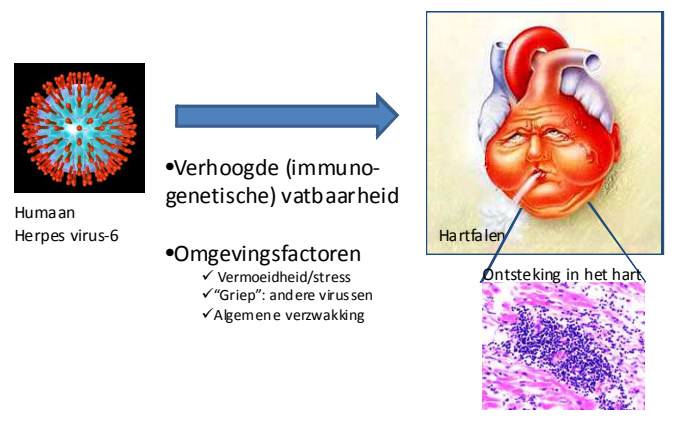
branden? Ik maak graag de vergelijking met het krijgen van vervelende koortsblaasjes. Bepaalde levensomstandigheden spelen mee: ziekte, andere virussen, vermoeidheid of de hormonale status zullen een persoon meer ontvankelijk maken voor deze vervelende koortsblaasjes. Doch steeds dezelfde mensen krijgen ze: dit is de immunogenetische achtergrond.

Zo ook in het hart: bepaalde verkoudheidvirussen wakkeren een overdreven ontsteking in het hart aan bij voorbeschikte mensen, en vaak in aanwezigheid van andere virussen. Hoe deze virussen

brandhaarden opsporen? Deskundige collega's cardiologen zoals Professor HP Brunner Larocca en Vanessa van Empel nemen kleine stukje hartspierweefsel uit het hart, waarin de aanwezigheid van hartspecifieke virussen worden aangetoond door de microbiologen. Hoe de brand blussen? Hiervoor gebruik ik gerichte anti-virale behandelingen. In studieverband bijvoorbeeld onderzoek ik of 
intraveneus immuunglobulines, die helpen bepaalde virussen zoals het ParvovirusB19 uit te schakelen in het hart, de pompfunctie van het hart kan verbeteren.

\section{Genetische oorzaken van plotse dood.}

Naast virussen, heb je ook de foute genen. Virussen en foute genen zijn ook bekend om het plots dood vallen van topsporters of atleten. Dramatisch, en schokkend. Eén enkel foutje in een gen die de structuur en ritme van het hart bepaalt, kan dodelijke hartritmestoornissen of hartfalen opwekken. Net zoals een foute schroef in het roer van een vliegtuig, een dodelijke crash tot gevolg kan hebben. Om deze foutjes in bekende genen te vinden, werken ikzelf, en collega Volders en Schalla samen met de klinische genetica. Met een simpele bloedprik en een verdere isolatie van deze genen uit onze bloedcellen is het mogelijk deze genen te ontrafelen! De uitkomst is belangrijk zowel voor de patiënt, alsook de familie. Voor de patiënt, omdat medicijnen of defibrillatoren de dodelijke ritme stoornissen kunnen voorkomen. Voor de familie, omdat deze hartziekte zich verder zet op de volgende generaties, meestal op een autosomaal dominante wijze: één op de twee van de ouders, broers, zussen of kinderen heeft de kans hetzelfde gen-defect te dragen en de hartziekte te ontwikkelen.

\section{Ontstekingen in het hart.}

Naast virussen en genmutaties, heb je ook ontstekingsziekten, die vaak zonder virussen ontstaan. Zo kunnen ontstekingsgebonden ziektes zoals reuma, sarcoidose waarvoor ik samenwerk met Prof. Drent, psoriasis of inflammatoire darmaandoeningen ook het hart plagen. Het zijn allemaal ziekten waarbij ontsteking één of meerdere organen ziek maakt. Ook het hart doet spijtig genoeg vaak mee: ik duid het dan aan als "reuma van het hart". Samen met de internisten en immunologen die zich toeleggen op de diagnostiek en behandeling van deze vaak complexe ontstekingsziekten, behandelen we het hart met ontstekingremmende medicatie. Deze aanpak belet verdere schade aan het hart, hetgeen de functie van het hart verbetert, en meermaals levensreddend is.

Deze polikliniek "Cardiomyopathieën" of jonge hartfalers ben ik zes jaar geleden gestart, en de gegevens van deze jonge hartfalers verzamel ik in één groot bestand. Verschillende puzzelstukjes zet ik samen om een betere kijk te krijgen op het zieke jonge hart. Vele vragen wil ik beantwoorden. Wat is de wisselwerking tussen de virussen, genen en ontsteking? Wat bepaalt de verslechtering of verbetering van de hartziekte? Kunnen we nieuwe diagnostische testen ontwikkelen, of meer gerichte behandeling toepassen? Wat is de plaats van beeldvorming? Hoe reageren deze mensen op de plaatsing van biventriculaire ICD's die het hart beter doen samentrekken (biventriculaire ICD's)? Deze en vele andere vragen zal ik, in samenwerking met mijn collega's cardiologen in Maastricht, en de andere cardiologische academische centra in Nederland binnen ICIN, verder beantwoorden.

Wat virussen, ontsteking en genen betekenen voor het krijgen van hartfalen, onderzoek ik ook mijn eigen laboratorium. Ik maak gebruik van dierexperimentele modellen en weefselkweken waarbij ik virussen inspuit, ontsteking veroorzaak, en genen manipuleer. Het beter begrijpen van het samenspel tussen een virale infectie, ontsteking en genetische fouten is uiteindelijk mijn doel. Belangrijkste vragen hierbij zijn: wat is die genetische achtergrond die bepaalt waarom één persoon wel hartfalen ontwikkelt in de aanwezigheid van een virus, en zoveel anderen niet? Welke virussen zijn schadelijk?

Wat is de rol van microRNAs bij het ontstaan van ontsteking, schade en littekenvorming in het hart? Deze "niet-coderende"microRNAs zijn genen die niet vertaald worden tot eiwitten, doch de expressie van de genen zelf bepalen, een soort tussenstap naar het eiwit toe. Nu onderzoekt mijn groep hoe deze nieuwe klasse van niet-coderende kleinere microRNAs of de grotere linc-RNAs (long noncoding RNAs), hartfalen door ontsteking of bindweefselvorming beïnvloeden.

\section{Europa stimuleert het wetenschappelijk onderzoek.}


Nu kom ik graag terug tot Europa, het bindweefsel van mijn hartonderzoek. Een groot deel van dit onderzoek gebeurt in een bredere Europese context. De Europese Unie is niet alleen belangrijk voor het stimuleren van de economische en politieke samenwerking, het helpt ook onderzoekers om de krachten te bundelen binnen grotere consortia. Zo ben ik momenteel betrokken bij een aantal Europese projecten, als coördinator, work package leader, of als partner. Professor dr. D. Brutsaert en Professor dr. W. Paulus zijn mijn mentoren in dit Europees gebeuren.

Het toenemend belang van Europa voor de funding van het onderzoekt weerspiegelt zich in de evolutie van mijn eigen werving. Waar in 2007 de hartstichting en de universiteit het grootste deel

\section{Funding van het onderzoek}

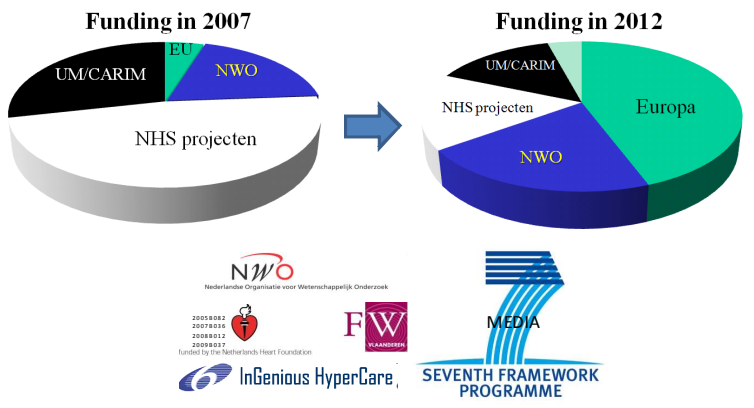

vormden, is het nu vooral Europa die het leeuwendeel levert.

Hierbij wil ik graag afronden. Het bindweefsel van mijn hart is Europa. Het staal luidde het begin in van de Europese eenwording, alsook van mijn eigen onderzoek. Crisissen in Europa, en zo ook virussen, ontsteking of een infarct, maken het hart ziek, doch leren ons heel veel over de werking ervan. Inzicht ons aangeleverd door wetenschappers, in Europa de technocraten, leidt tot betere aansturing. De Europese politici verwerken deze kennis tot nieuwe wetmatigheden,

middelen om de Europese Unie beter aan te sturen.

Als verschillende volkeren van Europa, zo ook België en Nederland, zijn we ons bewust van ons gemeenschappelijk geestelijk en wetenschappelijk erfgoed, gebaseerd op vrijheid, overleg, gelijkheid en samenwerking. Dit erfgoed is ingebed in onze democratie, de Europese Unie, en in de verschillende samenwerkingsverbanden in Nederland en Europa. De Europese Unie en de Nederlandse samenwerkingsverbanden stellen zich ten dienste van de mens, die ruimte nodig heeft om op een vrije en creatieve wijze de kennis te vergroten. De Universiteiten staan garant voor deze universele waarden van vrijheid, overleg en solidariteit. Het bindweefsel dat mijn hart en het onderzoek bijeen houdt, vind ik terug in deze onderzoeksscholen, interuniversitaire instituten zoals ICIN, en bovenal de Europese Unie.

\section{Dankwoord.}

$\mathrm{Nu}$, mijn dankwoord.

Dat ik hier vandaag mag staan, dank ik aan meer mensen dan ik nu kan noemen.

Mijn werk is als een boom die groeit dankzij de hulp en input van familie, vrienden en collega's. Mijn wortels liggen bij mijn ouders en het gezin waarin ik ben opgegroeid. Mamie en Papie, dankzij jullie opvoeding in geest en daadkracht, sta ik hier nu als gedreven, nieuwsgierige en optimistische persoon. Papie, zussen en broer, we hebben mamie moeten loslaten verleden jaar: echter haar zorg en liefde leven verder diep in ons.

Ann, mijn lief schatje, zonder jouw dagelijkse steun en onbegrensde liefde stond ik hier nu niet. Jij bent mijn dagelijkse levenssap waardoor ik als mens en onderzoeker kan groeien. Je hebt me gestimuleerd in mijn doctoraat, mij de vrijheid gegeven te werken in Maastricht en Nederland, en de ruimte gelaten om de uitdagende combinatie kliniek, onderwijs en onderzoek mogelijk te maken, dit reizend tussen Maastricht, Leuven en Utrecht. Lieve kinderen, Sophie, Paul en Astrid, onze oogappels: jullie boompje is nog jong, doch jullie levensvreugde en groeikracht des te groter. Groei ook op tot nieuwsgierige en leergierige mensen: mama en ik hebben het volste vertrouwen in jullie. Heverlee bos zal steeds voor jullie open staan. 
Professor dr. Peter Carmeliet en Professor dr. Désiré Collen, en ook mijn eigen schoonmoeder en "oma" Prof.dr. Magdalena Lodeweijckx, leerden mij de eerste stappen in de wetenschap aan de Universiteit van Leuven. Zijn ontkiemden mijn eerste wetenschappelijke interesse in de plotse dood "mors subite", en hielpen mij dit wetenschappelijk werk te doen groeien tot een kunstwerk van collageen en staal. Professor Désiré Collen bracht mij steeds met de twee voeten weer op de grond, en met de klinische studies die ik uitvoerde voor hem, wist ik te onthouden dat de patiënt tenslotte baat moet hebben bij het onderzoek. Mijn muizen die voor de voeten van de Vlaamse Minister van Wetenschap Fientje Moerman trippelden bij haar bezoek aan het lab, toen ik een patiënt in nood moest helpen, heeft hij me gelukkig dan ook vergeven.

Professoren Yigal Pinto, Harry Crijns en Mat Daemen hebben me de kans en het geluk gegeven om in Maastricht te komen werken en mijn droom te doen uitkomen om onderzoek, kliniek en onderwijs op degelijke en aangename manier te combineren. Prof.dr. Crijns, het hoofd vakgroep cardiologie, geeft me steeds veel ruimte en steun om zowel binnen het moleculair als klinisch onderzoek te groeien. Prof.dr Yigal Pinto, mijn fantastische mentor in mijn eerste jaren Maastricht, ik heb veel geleerd van zijn journalistieke welbespraaktheid, en zijn grote geestdrift in het onderzoek.

Mijn vele collega's in de afdeling Cardiologie, en daarbuiten, ik waardeer het werk van jullie allen bijzonder. Het hartfalen team, de interventie cardiologen en de elektrofysiologen: jullie klinisch en wetenschappelijk werk is bijzonder. Dankzij jullie dagelijkse inzet mag ik heerlijk "asociaal zijn in de wetenschap", zoals Dr. Cheriex het verwoordt.

Dr. Blanche Schroen, dr. Anna Papageorgiou en dr. Marc van Bilzen zijn de wetenschappelijke "senior" krachten binnen mijn groep die de vele projecten helpen vorm geven. Ik weet dat ik wetenschappelijk ideeën als bladeren in de herfst laat dwarrelen, doch hieruit pikken jullie het beste op. Dank voor jullie dagelijkse steun en harde werk. Ook Rick van Leeuwen,Wouter Verhesen, en Paolo Carai, alsook Kevin, jullie zijn de stevige eiken in ons lab waar vele AIO's op steunen, en hun vierjarig kampje tegen bouwen. Jullie aller werk, en het werk de vele AIO's is onmisbaar: zonder jullie kan ik het niet.

Zeer gewaarde dr. Paul Volders en Prof.dr. Leon de Windt, samen vormen we nu een stevig Maastrichts bos binnen de vakgroep Cardiologie: de universiteit hoort van waar de wind waait.

Mijnheer de Decaan Albert Scherpbier, en alle bestuursleden van de Universiteit Maastricht en het Academisch Ziekenhuis, hartelijk dank dat ik hier mag werken. Ook ik wil mij inzetten om deze tot Gotische hoogtes te brengen binnen Europa en de wereld.

Lieve Ann, kinderen, oma, familie, vrienden en collega's, het woord stopt hier, Carpe Diem, laat ons genieten van een heerlijk samenzijn in vriendschap en genegenheid.

Ik heb gezegd. 